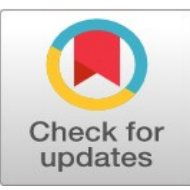

\title{
Mass lecture in language learning: What do the boys and girls think?
}

\author{
Nor Hidayati Abdullah ${ }^{1 *}$, Nur Hani Laily Ramli ${ }^{2}$, Mahfuzah Rafek ${ }^{3}$ \\ 1, 2, 3 Academy of Language Studies, Universiti Teknologi MARA (Tapah Campus), Tapah, Malaysia
}

\author{
Key Words \\ Gender \\ Mass lecture \\ Second language \\ Acquisition \\ English \\ Learner differences
}

Received: 3 November 2016

Accepted: 17 March 2017

Published: 21 April 2017

\begin{abstract}
This exploratory study is aimed to investigate learners' insights on the suitability of mass lecture and its reasons based on genders' experience. Having to cope with many students, many universities have been practicing mass lecture with no limitation to any particular field of studies (Bowman and Mete, 2014). In ESL classrooms, the mass lecture has become more common as one of the possible solutions for the shortage of workforce or English language teachers and lecturers, including in Malaysia. However, the students' experience in mass lectures in learning the second language may vary due to the gender differences in language learning. In this quantitative study, a set of questionnaires was used as the instrument for data collection. The sample of this study was a total of 206 students from a local university. Significantly, it was found that mass lecture in language learning is perceived suitable by both male and female students. Nevertheless, there is a difference in the views of male and female students regarding learning speaking in mass lectures.
\end{abstract}

(C)2017 The Author. Published by TAF Publishing.

\section{INTRODUCTION}

Since learning language has been recognized to be an essential part in life, most universities from all around the world are making it compulsory for the students to enroll in English language classroom. The phenomenon is very apparent here in Malaysia where it is compulsory for public university students to pass the Malaysian University English Test (MUET) with Band 3 in order to further their degree.

Though English language portrays enormous magnitude in life, there are still some issues emerging during the process of learning it particularly at tertiary level (Trang et al., 2012). One of them is the shortage of manpower or English language teachers and lecturers in Malaysia. Thus, one of the possible solutions to this particular problem is by using mass lecture in teaching English.

Increasing class size in a learning setting has been debated and analyzed for several decades (Jenkins, 2014). The premise seems logical with the increasing issues like limited manpower to teach especially in language teaching. With the growing number of students' enrolment in every semester, most universities have tried to opt for using big classroom size or mass lecture particularly in tertiary level. It is perhaps one of the best options as it would definitely not only solve the problem but at the same time reduce the cost as put forward by Rios (1998) and Hui and David (2008).

\footnotetext{
${ }^{*}$ Corresponding author: Nor Hidayati Abdullah

†Email: norhidayati@perak.uitm.edu.my
} 
The issue of class size to determine the effectiveness of learning has become a widely discussed issue in the community of language learning particularly. It will then make it easier for the institution itself to focus on students' performance when some tests or evaluations are conducted at the same class. However, Chingos and Matthew (2011) mention that bigger classroom size comes with its own hiccups. Among them are students' performance and ample feedback to students. Some might have difficulties in terms of feedback and attention given by the lecturers. Slater et al. (2007) state that gender too plays an important role in determining whether the teaching and learning has successfully happened. Since male and female have different ways of learning, it too might become a factor to determine whether conducting language learning in mass lecture setting is a success or a failure.

Thus, this paper is aimed to investigate the suitability of mass lecture in language learning by looking at gender differences and experience in learning. The research question of this paper is:

RQ1: Is mass lecture suitable to be conducted for English language classes based on gender?

\section{LITERATURE REVIEW}

\section{Class size}

Large class or more commonly known as mass lecture is becoming a universal phenomenon in most universities as it is, more often than not, employed for content-based subjects or theory-based subjects. However, in certain universities, due to some reasons especially shortage of manpower and for the sake of cost effectiveness (Hui and David, 2008), this mode of teaching is also widely practiced for skill-based subjects like language class.

The definition of large class varies from context to context, teacher to teacher and university to university (Hayes, 1997; Thaher, 2005). Some educators may agree that having more than 50 students in a language class is considered to be 'large class' already while some may disagree. In this present study, the large class referred to is a class in which there are 60 or more students, thus entitled to also be referred to as 'mass lecture' due to the large number of students.

From time to time, there has been a lot of research and continuous debate over the issue of class size for an effective language learning to take place. According to Izzo (1981), class size is a significant physical factor in language learning as it influences the choice of method and reduces the amount of individual attention that a teacher can give to each student. She found that small class is more preferable for language learning and correlated significantly with language achievement. This finding is supported by Sabander (1989) who studied English language learning in large classes at the universities in Indonesia. Bennet (1996) and Hargreaves (1997) also put forward that most parents and teachers favour smaller classes as they claimed larger classes would negatively affect many aspects of learning especially attitudes, interest, time for individual attention and teacher-student relationship. Nevertheless, there has been very few research conducted to gauge the students' experience or perspective regarding class size. The closest would be Thaher (2005) who investigated the effects of large class on EFL students at a local university in Palestine. Among the findings is there are no significant differences for students' gender, level of study, college, and placement test marks across the three domains namely instructional, psychological and social effects. In the study, the sample were 230 first, second, third and fourth year students who were learning English as a university requirement. However, this present study only focuses on gender in investigating the differences that the students may have experienced. 


\section{Arguments for and Against Large Class}

Studies have been conducted to investigate the positive relationship between large class students' achievement and a number of them refutes the claim of "smaller is better" (Blake, 1954; Fleming, 1959; Sitkei, 1968). For example, according to Hanushek (1998), it was found that there is no significant relationship between class size and achievement and students' achievement is not influenced by class size alone.

In terms of the teaching and learning process, studies suggest that a large class size does not necessarily cause difficulties for educators and learners. This is because most lecturers are able to achieve positive learning outcome regardless of class size by using effective teaching methods (Wößmann and Martin, 2002).

Conversely, there have been arguments made against large class which commonly come from ESL/EFL practitioners or educators as they are the people who have to deal with managing the class on everyday basis. Upon reviewing the literature, although small class size does not directly influence students' achievement, it does play a mediatory role to the other variables that directly influence students' achievement. Horning (2007) posits smaller class size benefits all parties involved in ESL writing classes namely teachers, students and program administrators in influencing students' success. She also cites Astin (1993) which reports low student-faculty ratio has a positive impact on students' satisfaction with regards to teacher-student relationship, quality of teaching, and students' experience in general.

National Council of Teachers of English in USA is also among the proponents for smaller class size. The council argued that teaching in small class influences students' academic performance, student engagement, long term success and also teacher retention. In the case of academic performance, the council admits that the effects of class size vary across levels. While small class can be effective in the primary level, little or no effect of it can be observed in secondary level. However, even in secondary level, small classes do positively influence the academic performance when the secondary students consist of students from the minority ethnic groups or with low English language literacy.

One of the most recurring arguments made to support smaller class size seems to revolve around small class tends to foster better teacher-student relationship (Horning, 2007; Resnick, 2003). Besides that, having smaller class allows the teacher to give special focus to at-risk students by giving them timely feedback on their task performance (Bahanshal, 2013). Students will also become more comfortable in participating in lessons. Smaller class also makes it easier for teachers to handle students' misbehavior (Mitchell et al., 1989; Finn et al., 2003).

\section{Genders and Language Learning}

There are many theorists and researchers who promote the arguments on whether different gender affects the learning. Slater et al. (2007) state that male and female have differences in how they learn and absorb information. This depends on their way to perceive information and knowledge presented in front of them. They have found that the use of multi-sensory modality references in learning is more preferred by female as compared to male. This can be connected to Jovanovic and Sally (1998) who mention that male and female experienced language learning differently which is later supported by Hoxby (2000) who found that peers in class affect students' performance where females tend to be more anxious on their peers' feedback in class.

According to Rosenfeld and Roy (1990), different gender does not affect whether they can communicate in class. Seiler (1996) mentions that it is a serious problem for learners who are unable to understand what others are saying and it is completely another 
problem to make others understand what they are saying. In this sense, communication breakdown happens when no understandable messages and information are transferred (MacIntyre and Robert, 1989). As a result, students do not gain anything from the lesson. Seiler (1996) further mentions that difficulties depend on the comprehension issues while communicating has nothing to do with gender.

Bracken and Michelle (1994) on the other hand claim that male students have the tendency to have difficulties than female students since female students tend to have a better interpersonal relationship with the lecturer and teachers which can be related to feedbacks. This relationship affects their emotions where they feel more relaxed and secured in class. Apart from that, Gardner (1985) also proposes that females normally do better than males in language classes due to positive attitudes they carry while learning the language.

According to $\mathrm{Na}$ (2007), male students are more strongly influenced by classroom procedures when it involves test. In her study, she has found that female students usually score higher than male students in English exams. Therefore, she has concluded that female students are more confident in their ability to learn a new language. On the contrary, male students who have higher frequency of language learning failure are inclined to attribute their bad performance in English classes to their low ability. As a result, they are more anxious when it comes to English language subject.

Nevertheless, there are other studies that contradict with the theory by Rosenfeld and Roy (1990). Wicks-Nelson and Allen (2006), for instance, claim that researchers have found that naturally, females do feel more anxious than males. This is due to many factors such as confidence, security, and superiority. Under certain circumstances, female tends to feel easily vulnerable and therefore leads to the feeling of anxiousness and worry while male on the other hand does obtain more self-control and ability to detach themselves from unpleasant feelings.

Additionally, a study conducted by Mejias et al. (1991) on the oral communication apprehension among Mexican American students in Texas found that Mexican American females in their study consistently produced higher communication score than the Mexican American males. This is similar to the desire of 'performing masculinity' as suggested by Coates (2004:138). However, female students too become more anxious whenever they do not understand the instructions given by instructor in class. Similarly, according to Coates (2004), female students have the needs to perform femininity in front of others especially the male students.

In spite of many studies related to gender differences in language learning and the arguments on class size made earlier, there is lack of research being done to explore the students' experience in learning language, particularly in a large class, since most of the previous studies centered on the language instructors' views or the students' performance. Therefore, this study seeks to investigate the suitability of mass lecture for English language classes according to gender.

\section{METHODOLOGY}

\section{Respondents}

The respondents of this study are 206 ( 48 males and 158 females) ESL tertiary-level learners who enrolled in mass lecture English classes in one of the public universities in Malaysia. They were semester one students with age range of 18-19 years old from various faculties such as Faculty of Accountancy, Faculty of Computer Science and Mathematics and Faculty of Applied Science. It is compulsory for all the learners to enroll in the English classes for the first three semesters in order to fulfill the university course requirement. 


\section{Instrument/Data Analysis}

A quantitative method was employed in order to acquire an insight into the learners' views based on gender whether a mass lecture setting is suitable for learning second language. This exploratory study also investigates their reasons about the suitability of learning English in mass lecture based on their experience. The instrument used to collect the data was a questionnaire. Reliability check was done and the result of the Cronbach's alpha for the questionnaire used for this study is 0.779 which shows that the internal consistency is acceptable.

The questionnaire consists of two different sections which are Section A for Personal details and Section B for the suitability of mass lecture items. Respondents were required to respond to 11 items based on their experience in learning English language in mass lecture setting. Five-point Likert Scale from 'Strongly disagree' (1), 'Disagree' (2), 'Uncertain' (3), 'Agree' (4) and 'Strongly Agree' (5) was utilized respectively. The data in this study is analyzed using Statistical Package for Social Science (SPSS) software version 20.0 for percentages and mean values which range from 1.00-3.00 (Low) and 3.01-5.00 (High).

FINDINGS

Based on the analysis of the data, majority of both male and female learners in this exploratory study believed that mass lecture classes that they have attended throughout 14 weeks of the semester worked for learning English.

According to their experience, among the reasons why the learners from different gender feel that mass lecture setting is workable for learning English are depicted in the tables below.

TABLE 1. Environment in learning English in mass lecture setting based on gender

\begin{tabular}{llllll}
\hline \hline No & Item & Male (mean) & Level & Female (mean) & Level \\
\hline 1 & $\begin{array}{l}\text { The place used for mass lecture is } \\
\text { suitable. }\end{array}$ & 4.06 & High & 3.63 & High \\
$\begin{array}{l}\text { 9. am comfortable learning in mass } \\
\text { lecture setting }\end{array}$ & 3.71 & High & 3.41 & High \\
\hline \hline
\end{tabular}

TABLE 2 . Feedback and attention received in mass lecture setting based on gender

\begin{tabular}{|c|c|c|c|c|c|}
\hline No & Item & Male (mean) & Level & Female (mean) & Level \\
\hline 2. & The lesson is conducted clearly & 3.71 & High & 3.71 & High \\
\hline 3. & $\begin{array}{l}\text { I get enough attention during } \\
\text { mass lecture }\end{array}$ & 3.40 & High & 3.23 & High \\
\hline 8. & $\begin{array}{l}\text { I received feedback on my assign- } \\
\text { ments on time }\end{array}$ & 3.81 & High & 3.61 & High \\
\hline
\end{tabular}

From the findings in Table 1, it is found that male and female learners believed that the place used for mass lecture is suitable (male $=4.06$, female $=3.63$ ) thus it makes them comfortable learning in mass lecture setting (male $=3.71$, female $=3.41$ ).

Not only that, based on Table 2, the other reasons that allow them to have good experience during mass lecture are because the lesson is conducted clearly with the $\mathrm{m}=3.71$ for both genders and they get enough attention during mass lecture (male $=3.40$, female = 3.23). Apart from that, both genders received feedback from their lecturer on time despite of the large class setting with the mean values of 3.81 for male and 3.61 for female. Based on Table 3, for English skills, male and female learners believed that they are able 
to understand listening (male $=3.79$, female $=3.66)$, reading $($ male $=3.92$, female $=3.84$ ) and writing (male $=3.67$, female $=3.61)$ components very well when learning through mass lecture. However, for speaking component, male learners have the higher mean value which is 3.02 whereby for female learners, the mean is low which is 2.70 .

TABLE 3 . Suitability of learning English components in mass lecture setting based on gender

\begin{tabular}{llllll}
\hline \hline No & Item & Male (mean) & Level & Female (mean) & Level \\
\hline 4. $\quad \begin{array}{l}\text { I am able to understand the listen- } \\
\text { ing component well. }\end{array}$ & 3.79 & High & 3.66 & High \\
5. $\quad \begin{array}{l}\text { I am able to understand the } \\
\text { speaking component well. }\end{array}$ & 3.02 & High & 2.70 & Low \\
$\begin{array}{l}\text { 6. I am able to understand writing } \\
\text { component well }\end{array}$ & 3.67 & High & 3.61 & High \\
7. I am able to understand reading \\
$\quad 3.92$ & High & 3.84 & High \\
\hline \hline
\end{tabular}

\section{DISCUSSION}

This study aims to investigate the learner's insights on the suitability of mass lecture and its reasons based on genders' experience. The result of this study found that both genders perceive that learning English in mass lecture is suitable. It is found that both male and female students equally agree that the classroom and the facilities provided by the institution are suitable to conduct language learning class in mass lecture. As mentioned by Chingos and Whitehurst (2011), physical setting of the classroom needs to be considered when conducting classes in mass lectures. This finding also concurs with Maslow's hierarchy of needs (Maslow, 1954) which also states that physiological needs must be fulfilled before self-actualization can be achieved (Santrock, 2008).

Other than that, this study indicates both genders agree that they got enough attention during mass lecture. Learning English language in mass lecture setting might be suitable since both genders agree that the lessons have been conducted clearly despite of the large number of students. This proves that mass lecture is suitable to be conducted for language learning among the tertiary students even though only one instructor is accountable for many students (Hui and Davis, 2008).

This might be due to the factor of the experienced lecturers who are able to create a non-threatening environment through using good teaching strategies which allow the lecturers to give ample attention to each student even though the class is conducted in a mass. This is supported by Von Worde (2003) and Levine (2003) who found that applying appropriate strategies and techniques from the lecturer's part helps in creating a conducive learning environment.

This finding also concurs with Wößmann and Martin (2002) that mention by using proper teaching techniques and strategies, experienced teachers can overcome the obstacles when teaching large class. This finding therefore disproved the claim by Izzo (1981), Bennet (1996) and Hargreaves (1997) that large class as in mass lecture limits the amount of individual attention that a teacher can give to each student.

On the other hand, conducting mass lecture to language learners presents no difference in feedback according to both genders. This shows that both male and female students obtained feedback of their task performance despite being in a large class. Therefore, this finding differs from common notion put forth by researchers such as Bahanshal (2013) that smaller class size makes it easier for the instructors to provide timely feedback to 
their students.

Both genders believe that the mass lecture classes they have attended work for learning language even though Schmucker (2015) claims that in general, mass lecture does not work well in learning process. However, same result is found in a study conducted by Thaher (2005) that there are no significant differences between students' experience based on gender regarding learning second language in a large class. On the other hand, Slater et al. (2007) mentioned that genders play a vital role in determining whether the learning has successfully happened in language classroom. This is referred to as the fact that male and female students have variety of learning preferences that might be subjected to determining the success or the failure of the learning process itself.

On the other hand, one difference that can be found on the experience in mass lecture based on gender is speaking. Male students report that they can understand the lecture while female students say that they have difficulties when speaking is taught in mass lecture. This is supported by Wicks-Nelson and Allen (2006) who propose that females feel more anxious than males due to several factors such as confidence, security and superiority. Females might feel more anxious when it comes to speaking since it might expose their mistakes in front of others. Coates (2004) believes that females naturally are more concerned about 'maintaining faces' in front of others especially male students. Male students, on the other hand, obtain more self-control and are able to detach themselves from unpleasant feelings. Nevertheless, this finding contradicts with Bracken and Michelle (1994) who state male students are more likely to encounter language learning difficulties compared to females due to lack of interpersonal relationship between them and their instructors. Gardner (1985), meanwhile, reports females tend to perform better due to their positive attitudes towards language learning.

\section{CONCLUSION}

The execution of mass lecture in English language learning might be one of the solutions when it comes to recurring problem of manpower shortage as it has been practiced widely. Still, this issue needs to be addressed and considered thoroughly since the large number of students in the large class are of different gender who might have differences in learning language. The study has found that there is not much of difference between male and female students in learning language in mass lecture setting as majority of them have a good experience. Aspects like environment, attention and feedback receive positive responses whereas speaking skill receives negative responses compared to the other skills.

Based on the findings, it can be concluded that mass lecture is possibly suitable to be conducted for English language classes at tertiary level regardless of the students' gender but it requires more consideration if mass lecture is to be implemented for teaching speaking skill. Still, certain caveats need to be addressed before conducting mass lecture such as providing comfortable environment, giving ample attention and providing timely feedback. As such, the lecturer assigned to conduct mass lecture must be skillful in handling such challenges. Therefore, it is suggested that lecturers who teach in mass lecture must be kept abreast with the current teaching techniques, theories and approaches to language teaching by joining workshops and trainings.

transitional provisions;

\section{LIMITATIONS AND RECOMMENDATIONS}

There are some limitations in the study which must be addressed in future. This study has left some unanswered questions. For instance, males report being able to understand speaking component when taught in mass lectures, it should be noted that the mean score 
is significantly lower when compared to other language skills. Therefore, this finding questions us whether it is really suitable for speaking to be taught in mass lectures. Hence, more research inn this regard is required in future.

\section{REFERENCES}

Abdul Amir, Abdul Rahman Z. 2015. Utilization of request mitigators by Omani learners of English and native speakers: A comparative study. International Journal of Humanities, Arts and Social Sciences 1, no. 4: 156-172.

DOI: 10.20469 /ijhss.20004-4

Astin, Alexander W. 1993. What matters in college? Four critical years revisited. San Francisco, CA: Jossey Bass.

Bahanshal, Dalal A. 2013. The effect of large classes on English teaching and learning in Saudi secondary schools. English Language Teaching 6, no. 11: 49-59. D0I: 10.5539/elt.v6n11p49

Bennett, Neville. 1996. Class size in primary schools: Perceptions of teachers, chairs of governors, and parents. British Educational Research Journal 22, no. 1: 33-56. DOI: 10.1080/0141192960220103

Blake, Howard. 1954. Class size: A summary of selected studies in elementary and secondary public schools. $\mathrm{PhD}$ dis- $\quad$ sertation, Columbia University, New York, NY.

Bowman, Nicholas D., and Mete Akcaoglu. 2014. "I see smart people!": Using Facebook to supplement cognitive and affective learning in the university mass lecture. The Internet and Higher Education, 23: 1-8.

DOI: $10.1016 /$ j.iheduc.2014.05.003

Bracken, Bruce A., and Michelle Crain R. 1994. Children's and adolescents' interpersonal relations: Do age, race, and gender define normalcy? Journal of Psychoeducational Assessment 12, no. 1: 14-32. D0I: 10.1177/073428299401200102

Chingos, Matthew M., and Whitehurst, Grover J. 2011. Choosing blindly: Instructional materials, teacher effectiveness, and the common core. The Brookings Institution, Washington DC., WA.

Coates, Jennifer. 2004. Women, men and language. 3rd ed. London, UK: Pearson Education Ltd.

Finn, Jeremy D., Gina M. Pannozzo, and Charles M. Achilles. 2003. The "why's" of class size: Student behavior in small classes. Review of Educational Research 73, no. 3: 321-368. D0I: 10.3102/00346543073003321

Fleming, Charlotte M. 1959. Class size as a variable in the teaching situation. Educational Research 1, no. 2: 35-48.

DOI: $10.1080 / 0013188590010203$

Gardner, Robert C. 1985. Social psychology and second language learning: The role of attitudes and motivation. London, UK: Edward Arnold.

Hanushek, Eric A. 1998. The evidence on class size. W. Allen Wallis Institute of Political Economy, Rochester, NY.

Hargreaves, Linda. 1997. The effects of major changes in class size on teacher-Pupil interaction in elementary school classes in England: Does research merely confirm the obvious? Paper Presented at the Annual Meeting of the American, Chicago, IL.

Hayes, David. 1997. Helping teachers to cope with large classes. ELT Journal 51, no. 2: 31-38.

DOI: $10.1080 / 0141192960220103$

Horning, Alice. 2007. The definitive article on class size. WPA: Writing Program Administration 31, no. 1-2: 14-34.

Hoxby, Caroline M. 2000. The effects of class size on student achievement: New evidence from population variation. Quarterly Journal of Economics 115, no. 4: 1239-1285. DOI: 10.1080/0141192960220103

Hui, Ming-Fai, and David L. Grossman. 2008. Improving teacher education through action research. New York, NY: Taylor \& Francis.

Izzo, Suzanne. 1981. Second language learning: A review of related studies. Arlington, VA: Information Analyses. Jenkins, Richard. 2014. Social identity. New York, NY: Routledge.

Jovanovic, Jasna, and Sally Steinbach K. 1998. Boys and girls in the performance-based Science classroom: Who's doing the performing? American Educational Research Journal 35, no. 3: 477-496. D0I: 10.1080/0141192960220103

MacIntyre, Peter D., and Robert C. Gardner. 1989. Anxiety and second-language learning: To ward a theoretical clarification. Language Learning 39, no. 2: 251-275. DOI: 10.1080/0141192960220103

Maslow, Abraham H. 1954. Motivation and personality. New York, NY: Harper.

Mejias, H, Applbaum RL, Applbaum SJ, and Trotter RT. 1991. Oral communication apprehension and Hispanics: An explISSN: 2414-3111

DOI: $10.20474 /$ jahss-3.2.5 
oration of oral communication apprehension among Mexican American students in Texas. Paper presented at the Annual Meeting of the International Communication Association, Chicago, IL, May 22-26.

Mitchell, Douglas, Cristi Carson, and Gary Badarak. 1989. How changing class size affects classrooms and students. California Educational Research Cooperative, University of California, California, CA. $\mathrm{Na}$, Zhao. 2007. A study of high school students' English learning anxiety. The Asian EFL Journal 9, no. 3: 22-34. National Council of Teachers of English. 2014. Why class size matters today. URL: www. ncte.org (accessed April 25, 2016). Pradhan, Samjhana. 2016. English language teaching: A next gate to social awareness. International Journal of Human-

ities, Arts and Social Sciences 2, no. 4: 156-158. DOI: 10.20469/ijhss.2.20005-4

Resnick, Lauren B. 2003. Class size: Counting kids can count. American Educational Research Association 1, no. 2: 1-4. Rios, Robert J. 1998. Class size: Does it really matter? New Horizons for Learning. Jersey, NJ: Person Education, Inc. Rosenfeld, Lawrence B., and Roy M. Berko. 1990. Communicating with competency. Rhode Island, RI: Brown Higher Edu- cation.

Sabander, Jacob. 1989. Language learning in large classes in Indonesia (Lancaster-Leeds language learning in large classes, research project, no. 9). Lancaster-Leeds Language Learning in Large Classes Research Project, Leeds, UK. Santrock, John W. 2008. Educational psychology. 3rd ed. New York, NY: McGraw Hill.

Schmucker, Stephan H. 2015. Cognitive activation in mass lectures through voting systems in the lecture theatre. The Online Journal of Quality in Higher Education 2, no. 2: 17-22.

Seiler, William J. 1996. Communication: Foundations, skills, and applications. New York, NY: Harper Collins College Pub- lisher.

Sitkei, E. George. 1968. The effects of class size: A review of the research. Research Series, 1967-1968. Los Angeles, CA: ERIC.

Slater, Jill A., Heidi L. Lujan, and Stephen E. DiCarlo. 2007. Does gender influence learning style preferences of first-year medical students? Advances in Physiology Education 31, no. 4: 336-342. DoI: 10.1080/0141192960220103

Thaher, Muna. 2005. The effects of large class on EFL students at An-Najah National University. An-Najah University Jour- $\quad$ nal Resources (Human Sciences) 19, no. 3: 1047-1092.

Trang, Tran Thi T., Karen Moni, and Richard B. Baldauf. 2012. Foreign language anxiety and its effect on student's determination on study English: To abandon or not to abandon. TESOL in Context 5: 1-14.

Whitehurst, Grover J., and Matthew M. Chingos. 2011. Class size: What research says and what it means for state policy. Brown Center on Education Policy, Washington, D.C., WA.

Wicks-Nelson, Rita, and Allen C. Israel. 2006. Behavior disorders of childhood. 6th ed. New Jersey, NJ: Person Education. Wößmann, Ludger, and Martin R. West. 2002. Class-size effects in school systems around the world: Evidence from between-grade variation in TIMSS. Discussion Paper No. 485, Forschungsinstitut zur Zukunft der Arbeit Institute for the Study of Labor, Bonn, DE. 